\title{
BRYOPHYTE DIVERSITY IN MOUNT PRAU, BLUMAH VILLAGE, CENTRAL JAVA
}

\author{
Lianah $^{1 *}$, Niken Kusumarini ${ }^{2}$, Fitriana Rochmah ${ }^{3}$, Fadla Orsida ${ }^{4}$, Mukhlisi ${ }^{5}$, \\ Milya Ulfa Ahmad ${ }^{6}$, Ainun Nadhifah ${ }^{7}$
}

Received : February 16, 2021

Accepted : April 24, 2021

DOI: 10.15575/biodjati.v6i1.11693

1,2,3,4 Department of Biology, Faculty of Science and Technology UIN Walisongo Semarang 50185 Central Java, Indonesia.

${ }^{5}$ Balai Penelitian dan Pengembangan Teknologi Konservasi SDA Samboja, Indonesia.

${ }^{6}$ Departement of Biology, Faculty of Mathematics and Natural Sciences, Universitas Sebelas Maret, Surakarta, Central Java Indonesia

${ }^{7}$ Cibodas Botanic Garden, Research Center for Plant Conservation and Botanic Gardens - LIPI, West Java Indonesia

e-mail:

*lianahk58@gmail.com

²kusumarini@walisongo.sc.id

3fitrianarahma@gmail.com

4fadla180192@gmail.com

5mukhlisi arkan@gmail.com

${ }^{6}$ milyulfa98@gmail.com

7ainun.nadhifah@lipi.go.id

*Corresponding author

\begin{abstract}
Bryophytes are a major component of the ecosystem in Indonesia. Due to their sensitiveness, the abundance and diversity of bryophytes in an ecosystem are influenced by environmental conditions. This study aimed to determine the diversity of bryophytes based on ecological parameters in the village of Blumah Kecaman Plantungan, Kendal Regency which is directly adjacent to the Mount Prau protected forest, Central Java. The data collection method used was the exploratory method and the descriptive exploratory method with survey techniques. Observation was carried out by exploring an area of 3 kilometers, every $1 \mathrm{~km}$ distance. An observation station was made consisting of station 1 Jiwan hamlet, station 2 Garung, and station 3 at Cengkek and Gondan springs. The specimens were identified based on taxonomic literature. Each species was collected as a specimen for further identification in the laboratory. Abiotic environment parameters such as temperature, humidity, altitude, light intensity, $\mathrm{pH}$ and slope were observed. The results showed that Blumah village still has high plant diversity, especially bryophytes. The more humid, the higher the place, the lower the temperature and light intensity, the more species diversity. Based on the identification results, 21 species were recorded, which includes 15 species of mosses, four species of liverworts, and two species of hornworts. The index value of bryophyte species diversity was in the medium category, and the index value of species richness and species dominance were at low levels.
\end{abstract}

Keywords: Abiotic environment parameters, Biodiversity, Blumah, Bryophytes, Mount Prau.

\section{Citation}

Lianah, Kusumarini, N., Rochmah, F., Orsida, F., Mukhlisi, Ahmad, M. U. \& Nadhifah, A. (2021). Bryophyte Diversity in Mount Prau, Blumah Village, Central Java. Jurnal Biodjati, 6(1), 23-35.

\section{INTRODUCTION}

Bryophytes are major component of Indonesia's ecosystems. As the second largest group of land plants after flowering plants, bryophytes play an important role in our understanding of early land plant evolution.
Of the total 18,000 species in the world, Indonesia has approximately $15 \%$ species identified (Cole \& Hilger, 2016; Retnowati et al., 2019). According to Bawaihaty et al. (2014), the abundance and diversity of bryophytes in an ecosystem are strongly influenced by environmental conditions. 


\section{Jurnal Biodjati 6(1):23-35, May 2021 \\ JURNAL BI@DIATI}

http://journal.uinsgd.ac.id/index.php/biodjati

As cryptogams, bryophytes are epiphytic and are found mostly living attached to various substrates, such as on plant stems, weathered wood, dead stems, or in rocks or soil (Ruggiero et al., 2015). Even so, most plants have an important role in the environment, especially in mountainous or hilly areas. Bryophyte is a component that maintains the balance of water and the cycle of nutrients in the forest. As for other functions, namely for food sources and as a habitat for living things around it (Damayanti, 2006).

The presence of bryophytes can be used as a bioindicator of environmental pollution. In addition, the environment in which they grow has a specific microclimate characteristic, resulting it vulnerable to environmental changes and disturbances. Nowadays, due to climate change, pollution, the loss and deterioration of natural habitat, and invasive alien species, bryophytes face serious threats. Several previous studies have shown that habitat conditions have affected the diversity of bryophyte species, such as various forest habitat (Ariyanti et al., 2008), Papandayan Nature Reserve (Windadri, 2014), along the Kabura -Burana River (Endang, 2020), and Mount Ungaran (Mulyani et al., 2015).

Mount Prau, 2,565 meters above sea level, is located in the Dieng Plateau area, Central Java, Indonesia. It is located at coordinates $7^{\circ} 11^{\prime} 13^{\prime \prime}$ S 109 55'22" E. Mount Prau is the boundary between the three districts, namely Batang Regency, Kendal Regency, and Wonosobo Regency. Blumah Village, one of the villages in the Plantungan District of Kendal Regency, is located at the foot of Mount Prau, directly adjacent to the Mount Prau Protected Forest. It is about $7 \mathrm{~km}$ from Plantungan District, $37 \mathrm{~km}$ from Kendal Regency, and $96 \mathrm{~km}$ from the capital city of Semarang.
Blumah is one of the undisturbed areas and has a high diversity of plants, including bryophytes. Additionally, this area, which is part of the Mount Prau Protected Forest landscape, has various habitat levels. Until now, there are still very few studies related to the bryophyte diversity in the area. This study aimed to determine the diversity of bryophytes and identify the mosses in Blumah Village. This research is expected to provide important information regarding bryophyte diversity, including conservation efforts and their use in the future.

\section{MATERIALS AND METHODS}

\section{Location}

This research was conducted in Blumah Village, Plantungan District, Kendal Regency from 12 December 2020 to 16 January 2021. Blumah Village is a highland area, with an altitude of 900-1300 $\mathrm{m}$ asl with a temperature around $20-25^{\circ} \mathrm{C}$ and $80 \%-90 \%$ humidity. The average rainfall in the area is quite high, about $70-570 \mathrm{~mm}$ per year (Figure 1).

\section{Bryophyte Sampling}

Exploration was conducted by using the method explained by Rugayah et al. (2005) in three different stations along three kilometers. Furthermore, every $1 \mathrm{~km}$ distance an observation station was made consisting of station 1 of Jiwan hamlet, station 2 Garung, and station 3 at Cengkek and Gondan springs. Bryophyte specimens were identified using taxonomic literature (Bartram 1939; Eddy 1988, 1990, 1996; Gradstein, 2011) and other literature. All names were based on the literature and identified based on The Plant List website to recognize the currently accepted name. Vouchers were deposited in UIN Walisongo herbarium. 
Jurnal Biodjati 6(1):23-35, May 2021

\section{JURNAL BI@DIATI}

http://journal.uinsgd.ac.id/index.php/biodjati
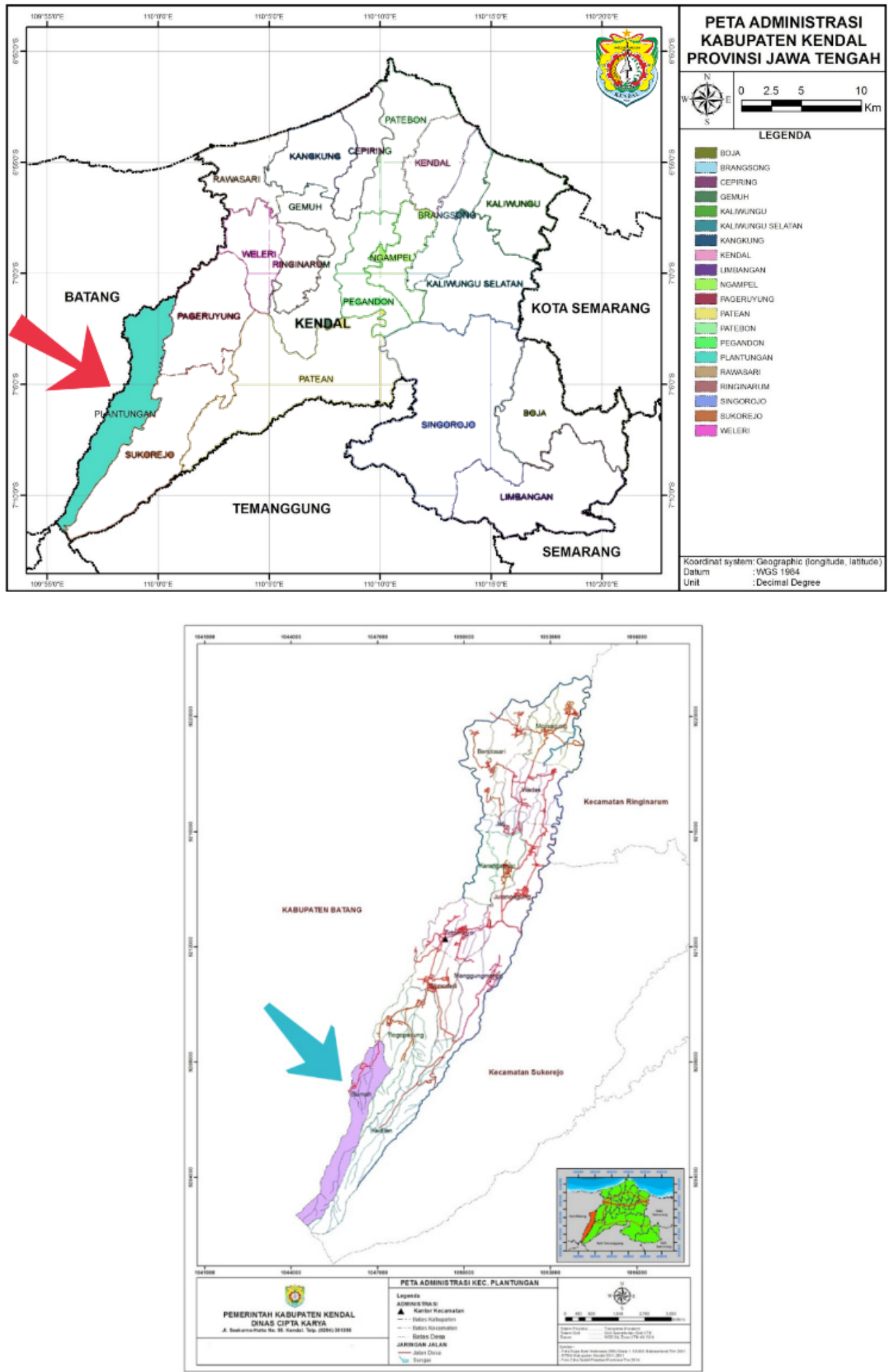

Figure 1. Map of research locations in Blumah Village, Plantungan District, Kendal Regency 


\section{Jurnal Biodjati 6(1):23-35, May 2021 \\ JURNAL BIDDJATI}

http://journal.uinsgd.ac.id/index.php/biodjati

\section{Data Analysis}

The specimens were analyzed descriptively based on their characteristics as well as the abiotic component of their habitat. Data analysis was carried out descriptively by tabulating the data obtained. To find out some of the ecological index parameters, calculations were also carried out on the Shannon Wienner Species Diversity Index (H), Species Richness Index, and Species Evenness Index (E). All calculations were carried out using the assistance of Software PAST. 3.1 (Hammer et al., 2001).

Table 1. List of bryophytes found in Blumah Village

\begin{tabular}{|c|c|c|c|c|c|}
\hline \multirow[b]{2}{*}{ Scientific name } & \multirow[b]{2}{*}{ Family } & \multirow[b]{2}{*}{ Substrat } & \multicolumn{3}{|c|}{ Location } \\
\hline & & & Station 1 & Station 2 & Station 3 \\
\hline \multicolumn{6}{|l|}{ Mosses (Bryophyta) } \\
\hline $\begin{array}{l}\text { Brachymenium indicum (Dozy \& Molk.) Bosch \& } \\
\text { Sande Lac. }\end{array}$ & Bryaceae & Tree & + & - & + \\
\hline Bryum argenteum Hedw. & Bryaceae & Rocks & + & + & - \\
\hline Calymperes tenerum Müll. Hal. & Calymperaceae & Rocks & - & + & + \\
\hline $\begin{array}{l}\text { Ectropothecium falciforme (Dozy \& Molk.) A. } \\
\text { Jaeger }\end{array}$ & Hypnaceae & Tree & + & - & + \\
\hline Fissidens atroviridis Besch. & Fissidentaceae & Soil & + & + & - \\
\hline Fontinalis antipyretica Hedw. & Fontinalaceae & Tree & - & + & - \\
\hline Hyophila apiculata M. Fleisch. & Pottiaceae & Rocks & + & + & + \\
\hline Hyophila javanica (Nees \& Blume) Brid. & Pottiaceae & Rocks & + & + & + \\
\hline Hypnum cupressiforme Hedw. & Hypnaceae & Tree & + & + & - \\
\hline Isopterygium minutirameum (Müll. Hal.) A. Jaeger & Hypnaceae & Tree & + & - & + \\
\hline Philonotis hastata (Duby) Wijk \& Margad. & Bartramiaceae & Tree & - & - & + \\
\hline Polytrichum commune Hedw. & Polytrichaceae & Soil & - & - & + \\
\hline Polytrichum strictum Menzies ex Brid. & Polytrichaceae & Soil & - & - & + \\
\hline Rhynchostegiella sp. & Brachytheciaceae & Tree & + & - & + \\
\hline Thuidium tamariscinum (Hedw.) Schimp. & Thuidiaceae & Tree & - & - & + \\
\hline \multicolumn{6}{|l|}{ Liverworts (Marchantiophyta) } \\
\hline Cyathodium smaragdinum Schiffner ex Keissl. & Cyathodiaceae & Soil & + & - & + \\
\hline Marchantia polymorpha L. & Marchantiaceae & Soil & + & + & + \\
\hline Radula sp. & Radulaceae & Tree & - & - & + \\
\hline Riccia junghuhniana Nees \& Lindenb. & Ricciaceae & Soil & + & + & - \\
\hline \multicolumn{6}{|l|}{ Hornworts (Anthocerotophyta) } \\
\hline Anthoceros sp. & Anthocerotaceae & Rocks & - & + & + \\
\hline Notothylas javanica (Sande Lac.) Gottsche & Notothyladaceae & Rocks & + & + & - \\
\hline
\end{tabular}

(Research data, 2020)

Lianah et al.

\section{RESULTS AND DISCUSSION}

\section{Bryophyte Diversity Species}

The bryophyte survey yielded 21 specimens of bryophytes. A total of 21 species and 16 families were identified, including 15 species of mosses, four species of liverworts, and two species of hornworts (Table 1). Field observations showed that station 3 has the most diverse species compared to other stations with 15 species found. Meanwhile, at the station 1 and 2, 11 and 13 species were identified, respectively. The bryophytes were found in various habitat, such as rocks, soil, cliff, and tree trunks. 


\section{Jurnal Biodjati 6(1):23-35, May 2021 \\ JURNAL BIDDJATI}

http://journal.uinsgd.ac.id/index.php/biodjati

Based on Table 1, the bryophyte flora of Mount Prau in all stations is dominated by numbers of mosses (Bryophyta). This is natural because mosses are known as a group of mosses that have the highest species diversity in the world. According to Goffinet et al (2008) Bryopsida covers $84 \%$ of families and as much as $98 \%$ of bryophytes. The distinctive characteristic of mosses is that it can be distinguished between the stems and leaves, so it is considered to have the highest level of development compared to other groups.

Compared to several previous bryophyte studies, such as that conducted by Endang (2020) around the Kaburan-burana watershed and Mulyani et al. (2015) on Mount Ungaran, the results of this study indicate a higher species diversity. However, the species found remain less than a study conducted by Windadri et al. (2014) and Windadri \& Rosalina (2017). This can be caused by differences and variations of environmental conditions. Each species has a suitable place to grow and different adaptive capabilities. In addition, the level of habitat disturbance in the form of anthropogenic factors can also affect the richness of bryophyte diversity in a particular location. Moreover, land use by humans can cause increased sunlight intensity and affect the ability of species adaptation.

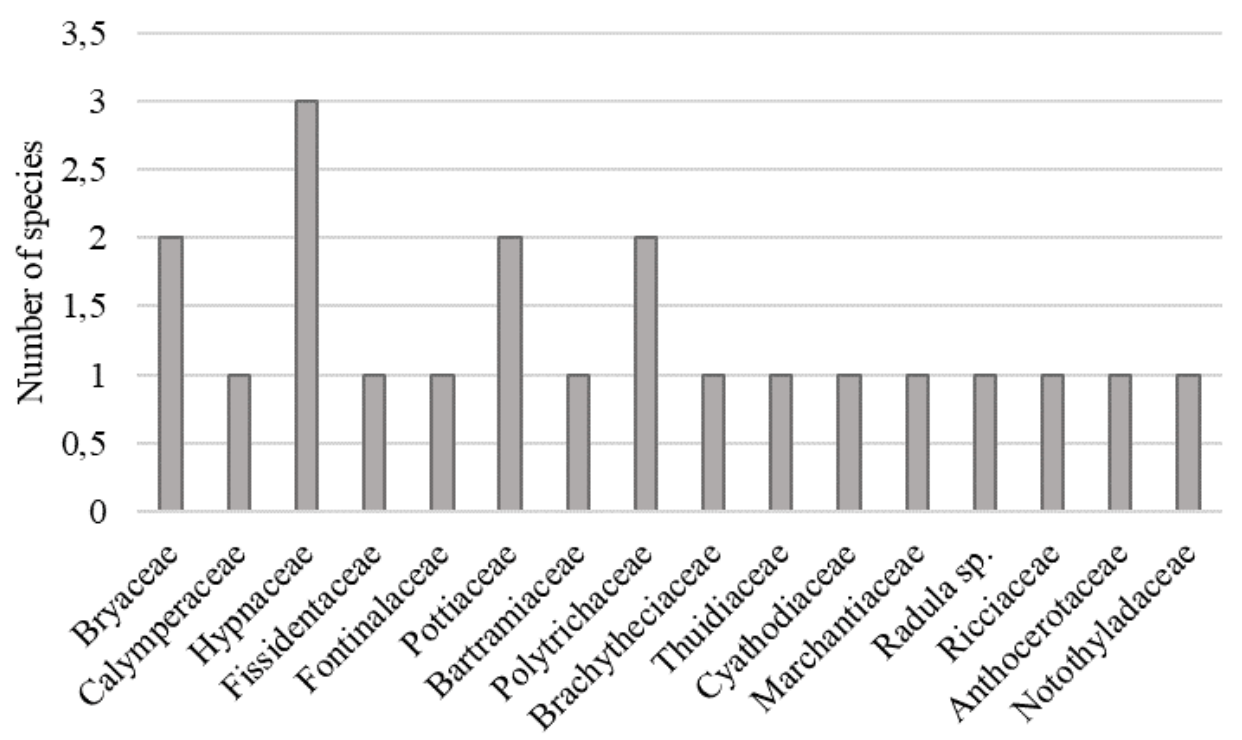

Figure 2. List of bryophyte families found at Mt. Prau, Blumah Village

Hypnaceae has the highest species member among the other identified families (Figure 2). The high species composition in Hypnaceae is in line with the findings of Mulyani et al. (2015), where the research location is nearby the location of this study. However, the most abundant species found in all stations were dominated by Pottiaceae. This species can adapt to environmental conditions with higher humidity and lower air temperature.

\section{Description and Potential Utilization of Bryophytes}

Of the 21 species of bryophytes, there are 15 species of mosses, four species of liverworts, and two species of hornworts. The following is a description of the characteristics of each species identified along with their potential uses. 
Jurnal Biodjati 6(1):23-35, May 2021

\section{JURNAL BIDDJATI}

http://journal.uinsgd.ac.id/index.php/biodjati

\section{Moses (Bryophyta)}
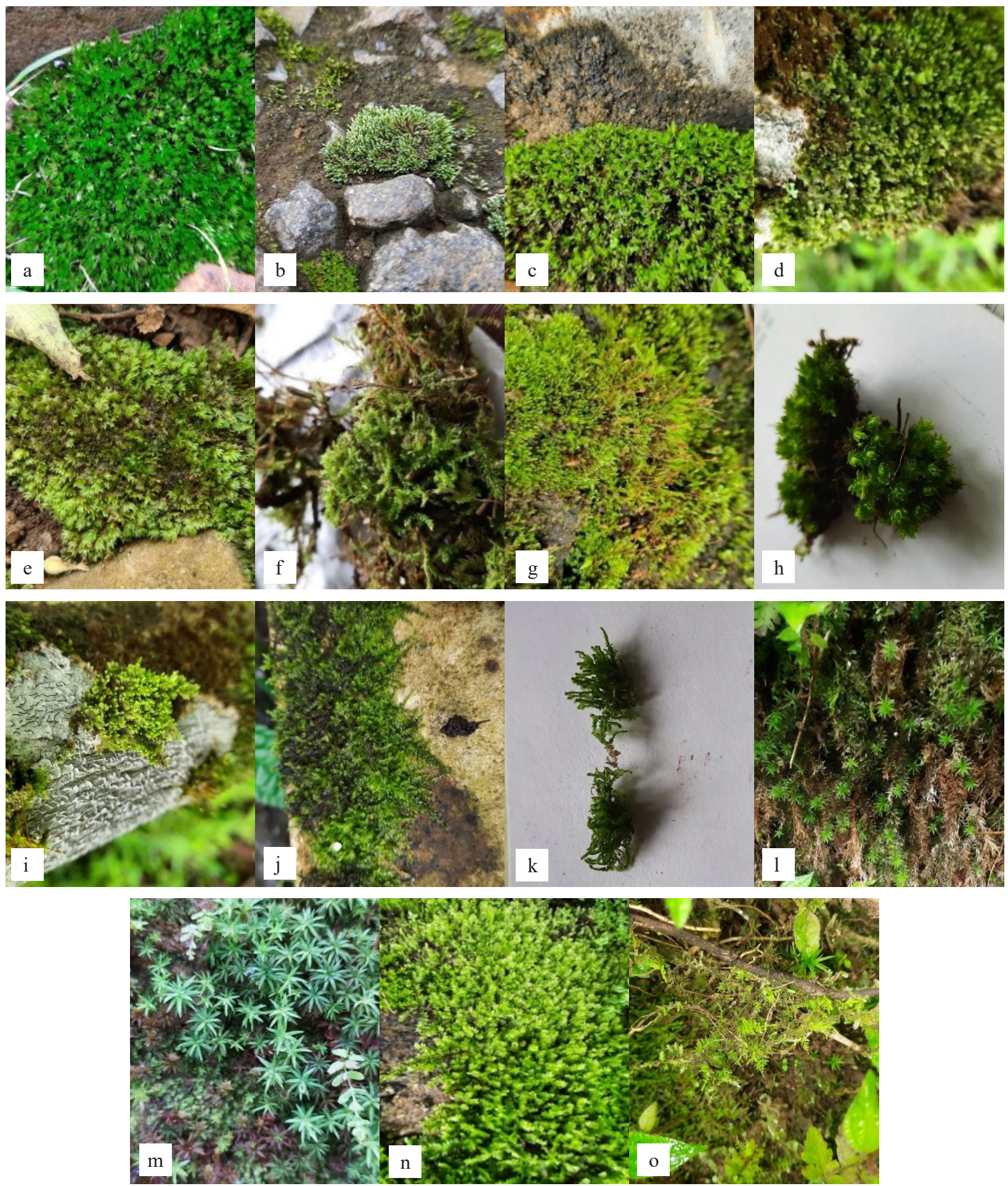

Figure 3. Mosses found at Mt. Prau, Blumah Village. a. Brachymenium indicum, b. Bryum argenteum, c. Calymperes tenerum, d. Ectropothecium falciforme, e. Fissidens atroviridis, f. Fontinalis antipyretica, g. Hyophila apiculata, h. Hyophila javanica, i. Hypnum cupressiforme, j. Isopterygium minutirameum,

k. Philonotis hastata, 1. Polytrichum commune, m. Polytrichum strictum, n. Rhynchostegiella sp., o. Thuidium tamariscinum 


\section{JURNAL BI@DJATI}

http://journal.uinsgd.ac.id/index.php/biodjati

Figure 3 shows the different characteristics of 15 species that are included in the mosses group. According to Lukitasari (2018), mosses have characteristics on the gametophyte starting from the leaf structure which includes cell ornaments, the cross-section of the midrib, and the detail of the leaf margins. The sporophyte characteristics includes the sporangium, forms, and sporangial protective structures. Mosses (Bryophyta) occur on various substrates, such as on bare soil, soil that has a sandy texture, rocks, tree trunks, and tree branches, in swamps, and rarely in the sea.

Brachymenium indicum (Dozy \& Molk.) Bosch \& Sande Lac. is included in the Bryaceae. Found on soil, has dense leaves, elongated in shape and pointed edges, arranged alternately on the stem so that the stem is not visible, short stem and small. It has a rhizoid which is about $1 \mathrm{~cm}$ long, seta and capsule (sporophyte), and an overall length of about $2 \mathrm{~cm}$ (Febrianti, 2015).

Bryum argenteum Hedw. belongs to Bryaceae. On rocks. It has horn-shaped leaves and is arranged tightly so that the stem is not visible. Has rhizoids and sporophytes at the tips of the leaves. Overall size $1 \mathrm{~cm}$ (Rini, 2019).

Calymperes tenerum Müll. Hal. belongs to Calymperaceae. Found attached to the cliff wall. It has small leaves, small stems, the leaves are arranged alternately, covering the stem, growing not too tightly. Looks like a star from the top view. The leaves elongated. Has seta and capsules, the overall size of about 2-3 cm (Febrianti, 2015).

\section{Ectropothecium falciforme (Dozy \& Molk.)}

A. Jaeger is included in Hynaceae. Found clinging to damp trees and creeping life. Leaves are very small about $1 \mathrm{~mm}$ in size, leaves ovate, arranged parallel to the trunk. Sporophyte was not found, has an overall size of about 3-4 cm (Febrianti, 2015).
Fissidens atroviridis Besch. is included in Fissidentaceae. Attached on rocks. It has clearly visible leaves with a wide shape and wavy, pointy ends like duck feet and stacked up in rows, a very short trunk that is not visible, seta and capsule and an overall size of 1 cm (Febrianti, 2015).

Fontinalis antipyretica Hedw. is a moss that is included in the family Fontinalaceae. Found stuck to a tree branch. It has very small leaves elongated with a size of $0.5 \mathrm{~mm}$, arranged parallel from leaf 1 to the other, the leaves have a pointed tip, have a stem of $2 \mathrm{~cm}$, and are small. Has rhizoid and already has seta and capsule (Sporophyte). And the overall size is about 2-3 cm (Triantono \& Ichwan, 2019).

Hyophila apiculata M. Fleisch. is included in Hypnaceae. Found attached to a rock on the cliff wall. This moss is very small and grows in batches with others. Has small leaves that are arranged alternately on the stem. It has rhizoids that stick to the substrate very strongly. Seta and capsule extending upward. Overall size is about 2-3 cm (Febrianti, 2015).

Hyophila javanica (Nees \& Blume) Brid. belongs to Pottiaceae. Found on the soil. This species looks like neat scales from the top view, has a small, short stem covered with leaves. The leaves, which have a slightly transparent green color, have rhizoids, and already have a seta and a capsule (sporophyte). Has an overall size of $1.5 \mathrm{~cm}$ (Febrianti, 2015).

Isopterygium minutirameum (Müll. Hal.) A. Jaeger is included in Hypnaceae. Found attached to logs. A creeping moss in a dense arrangement and forms a smooth braid. Leaves shape oval with a tapered tip, tightly arranged on the stem. The stem sticks to the tree or the substrate. The overall size is about $3-4 \mathrm{~cm}$.

Polytrichum commune Hedw. belongs to Polytrichaceae. Found clinging to a cliff. Has a strong rhizoid clinging to cliffs, the shape is like a star with spiny leaves. Small and long 


\section{Jurnal Biodjati 6(1):23-35, May 2021 \\ JURNAL BIDDJATI}

http://journal.uinsgd.ac.id/index.php/biodjati

stem. Has a sporophyte at the tip of the leaf. Overall size 4-5 cm (Imu et al, 2019).

Polytrichum strictum Menzies ex Brid. belongs to Polytrichaceae. Found clinging to a cliff. Has strong rhizoid clinging to cliffs. Has a shape like a star, spiny leaves. Stems are small and short. Has a sporophyte at the tip of the leaf. Overall size 2-3x cm (Imu et al., 2019).

Rhynchostegiella sp. is included in Brachytheciaceae. Found attached to the soil. Has small, elongated leaves with pointed ends. The stems are small and short, covered by leaves. It grows close to one another like a soft green rug. Rhizoid, sporophyte, and overall size of 2-3 cm (Rini, 2019).

Thuidium tamariscinum (Hedw.) Schimp. belongs to Thuidiaceae. Found clinging on a tree with soft, branching, and conical leaves. Seta short and has a small stem and overall length about of 2-3 cm (Imu et al, 2019).

\section{Liverworts (Marchantiophyta)}

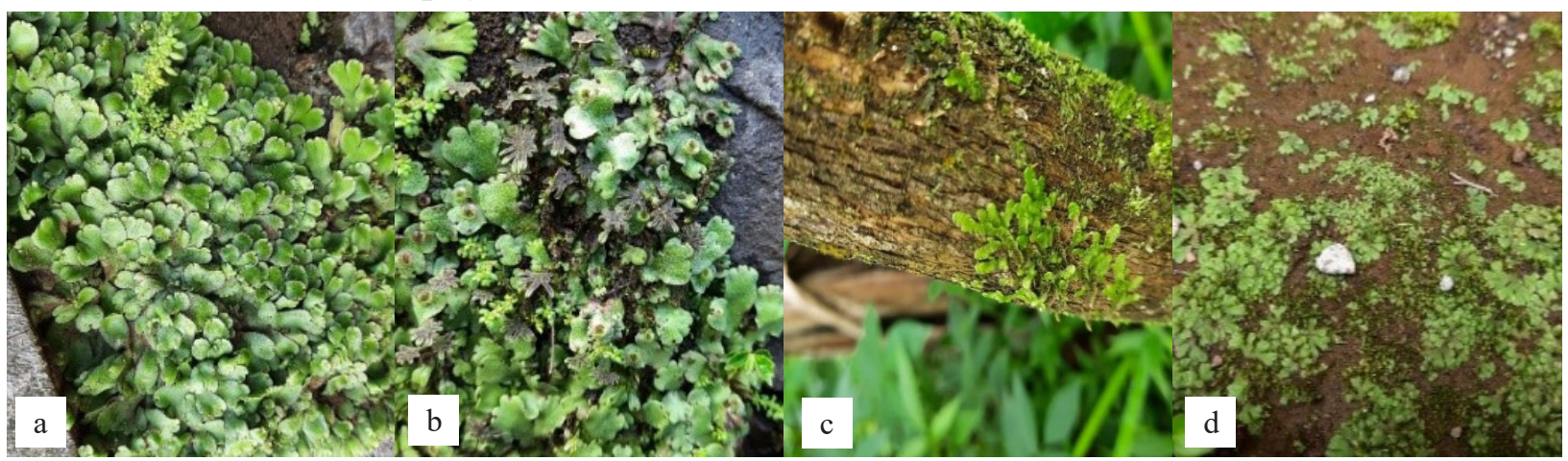

Figure 4. Liverworts found at Mt. Prau, Blumah Village. a. Cyathodium smaragdinum, b. Marchantia polymorpha, c. Radula sp., d. Riccia junghuhniana

Figure 4 depicts the morphology of four liverwort species found during this study. Liverworts are divided into 2 main groups based on their morphological gametophyte: leafy liverworts and thalloid liverworts. The gametophyte of leafy liverworts consists of stem and leaves whereas thalloid liverworts consists of the thallus, which is attached to the substrate by one-celled hairs, rhizoids (Gradstein et al., 2011). Lukitasari (2018) mentioned that liverworts usually grow on soil and can be identified by some characters such as thallus shape, cellular structure, and the position of sexual organs.

\section{Cyathodium smaragdinum Schiffner ex}

Keissl. is included in the Cyathodiaceae family. This thalloid liverwort was found attached to the rocky wall. The leaves wide, measuring about $1.5 \mathrm{~cm}$, with long, wavy edges. The location of the sporophyte at the tip of the leaf (Febrianti, 2015).

Marchantia polymorpha $\mathbf{L}$. is a popular thalloid liverwort that belongs to the family of Marchantiaceae. The species was attached to the rocky wall. Has slightly large leaves measuring about $1-1.5 \mathrm{~cm}$. The leaves have a 3 -pronged shape with many wavy ends. The location of the spores is in each leaf wave, which has an umbrella-like sporophyte apparatus, measuring $1 \mathrm{~cm}$ (Febrianti, 2015). This species can be utilized as a drug for hepatitis $\mathrm{C}$ and diabetes (Jensen et al., 2012).

Radula sp. Taylor is included in the Radulaceae family. This species was found attached to the pound alongside the lichen. This species looks like a pile of leaves without a stem. 


\section{Jurnal Biodjati 6(1):23-35, May 2021 \\ JURNAL BI@DIATI}

http://journal.uinsgd.ac.id/index.php/biodjati

Small size (about $2 \mathrm{~mm}$ ). It has rhizoids that are very tightly attached to the substrate. We don't see the set or capsule yet (Rini, 2019).

Riccia junghuhniana Nees \& Lindenb. belongs to the Ricciaceae family. We found two specimens on the site. Clinging to the ground and living side by side with horns. It has long, heart-shaped leaves about 1-2 $\mathrm{mm}$ in size, arranged in a circle like a flower. The rhizoid is short and easy to be sampled. Sporophytes absent (Febrianti, 2015).

\section{Hornworts (Anthrocerotophyta)}

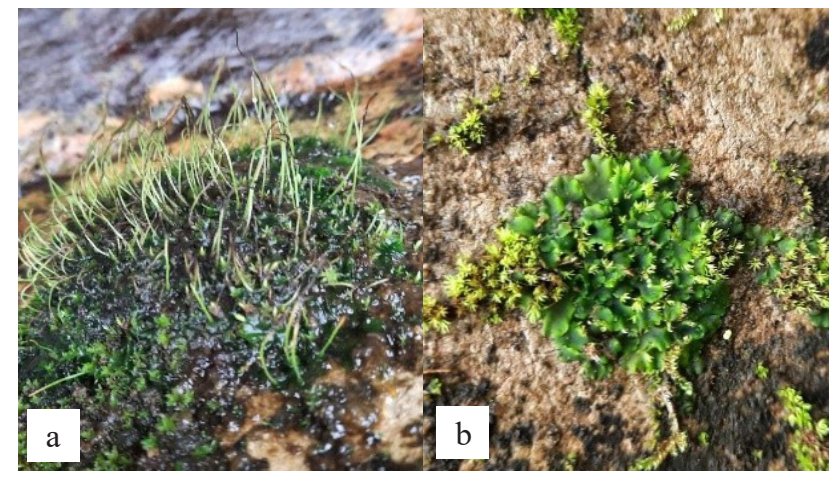

Figure 5. Hornworts found at Mt. Prau, Blumah Village. a. Anthoceros sp., b. Notothylas javanicus

Figure 5 shows the morphology of two hornworts found at Blumah Village. According to Lukitasari (2018), hornworts always have a horn-shaped sporophyte structure, with embedded sexual organs. Having the structure of the thallus, especially its internal anatomy and cell contents, is an observable important for classification. Likewise, the sporophyte (which contains sporangial walls, spores and their ornamentation, and sterile cells mixed with spores) and sterile cylindrical structures (if any) in the sporangium.

Anthoceros sp. belongs to the Anthocerotaceae family. Found attached to the soil along the river. Has long-like-horns structure. The sporophyte is at the tip of the leaf. Leaves about 2 cm long. It sticks tightly to the substrate and has rhizoids (Febrianti, 2015). This species is used as a bioindicator of air pollution and aa alternative cough medicine.

Notothylas javanica (Sande Lac.) Gottsche is included in the Notothyladaceae family. Found clinging to a cliff. Having leaves with pointed ends, the leaves are stacked together. Seen from above like a flower and green. Does not have seta and capsules. Has strong rhizoid. Leaf size $3 \mathrm{~mm}$ (Febrianti, 2015). This species is good as the bioindicator of air pollution, as a detector for mineral and plant content as well as ward off pests and insects.

\section{Species Diversity}

The characteristics of the environment where bryophytes grow in Blumah Village have various variations for each observation station. In general, the conditions are characterized by relatively low temperatures, moderate to high humidity, low light intensity, high soil moisture, relatively steep land conditions, and normal soil $\mathrm{pH}$. The results of observations show that the environmental conditions in Blumah Village have relatively high suitability of habitat for various types of bryophytes to reproduce. The results of the habitat are presented in Table 2. 


\section{JURNAL BIDDJATI}

http://journal.uinsgd.ac.id/index.php/biodjati

Table 2. Environmental conditions where bryophyte grows in each station.

\begin{tabular}{lccc}
\hline \multicolumn{1}{c}{ Parameter } & \multicolumn{3}{c}{ Location } \\
\cline { 2 - 4 } & Station 1 & Station 2 & Station 3 \\
\hline Air temperature $\left({ }^{\circ} \mathrm{C}\right)$ & $23-26$ & $23-25$ & $22-24$ \\
Humidity $(\%)$ & 70 & 75 & $80-85$ \\
Light intensity $(\mathrm{Cd})$ & 43 & 50 & 33 \\
Height (m dpl) & 775 & 840 & 954 \\
Soil moisture $(\%)$ & $60-70$ & $70-80$ & $80-90$ \\
The slope of the land $\left({ }^{\circ}\right)$ & 60 & 70 & 80 \\
soil pH & 6.8 & 6.7 & 7.0 \\
\hline
\end{tabular}

(Research data, 2020)

The calculation on several ecological index parameters produces various values among the stations. However, in general, the values were not significantly different. The value of the species diversity index $(\mathrm{H})$, species richness index, and evenness index (E) are shown in Table 3.

The diversity index of all observed stations is in the range of 2-3 and can be categorized at a medium level. This implies the ecosystem in which the bryophyte habitat found also has a moderate level of stability. Station 3 , which has a higher species diversity index value than the other stations, is probably due to a suitable condition of the habitat. In addition, location of station 3 is at a higher location, with lower temperature, and higher humidity which can support the life of the bryophyte population. The high humidity and soil in the bryophyte habitat at station 3 are also caused by its proximity to water sources. Furthermore, the index value of bryophyte species richness generally has a value of $\leq 2.5$ at all observed stations. This situation describes the conditions of low species richness.

Table 3. The index values for species diversity, species richness, and species dominance

\begin{tabular}{lccccccccc}
\hline \multirow{2}{*}{ Index } & \multicolumn{3}{c}{ Station 1 } & \multicolumn{3}{c}{ Station 2 } & \multicolumn{3}{c}{ Station 3 } \\
\cline { 2 - 10 } & Value & Lower & Upper & Value & Lower & Upper & Value & Lower & Upper \\
\hline Shannon Diversity & 2.52 & 2.382 & 2.523 & 2.315 & 2.189 & 2.345 & 2.647 & 2.558 & 2.659 \\
Richness & 2.578 & 2.578 & 2.578 & 2.051 & 2.051 & 2.051 & 2.587 & 2.587 & 2.587 \\
Dominance & 0.084 & 0.083 & 0.106 & 0.108 & 0.100 & 0.134 & 0.075 & 0.073 & 0.087 \\
\hline
\end{tabular}

Based on Table 3, Shannon (H) and Weiner shows that the highest bryophyte community is at station 3 near the Cengkek and Gondan springs with a $\mathrm{H}$ value of 2.647, indicating a moderate level of diversity. The diversity of bryophytes which were found in the Garung area and in Jiwan Hamlet, the $\mathrm{H}^{\prime \prime}$ value of 2.051 and 2.578 , respectively. The index value of bryophyte diversity is also in the medium category. This is because the conditions in the three areas were not much different. The dominance of a species is influenced by the maximum adaptability to abiotic and biotic environmental factors (Haryanto et al., 2008). Domination will occur when there is competition among the species. When the competition occurs, the ability to survive of such species in a particular condition will also increase. Thus, the species with high surviving ability suppresses the other species. In contrast, less adaptive species tend to have low reproductive rates, causing a decreasing 


\section{Jurnal Biodjati 6(1):23-35, May 2021 \\ JURNAL BI@DIATI}

http://journal.uinsgd.ac.id/index.php/biodjati

number of these species (Maisyaroh, 2010).

The ecological role of bryophyte in Mount Prau at Blumah village, especially in Jiwan and Garung hamlets was less than optimal due to local community activities such as gardening, disrupting the growth of the bryophytes. This is in line with the results of the research carried out by Bawaihaty et al. (2014) in the Sesaot Lombok forest, Nusa Tenggara, that bryophyte cannot grow optimally because the location is disturbed by the community for gardening. According to Bawaihaty et al. (2014), the abundance and diversity of bryophyte in an ecosystem are strongly influenced by environmental conditions.

At station 3 near the Cengkek and Gondan springs in which the land is still maintained and fewer community activities, the bryophytes grow optimally with high humidity $(80-90 \%)$ and temperature $\left(22-24^{\circ} \mathrm{C}\right)$ and low light intensity $(33 \mathrm{Cd})$. This is in accordance with Aryanti et al. (2008) which stated that bryophyte growth is influenced by high humidity, sufficient light intensity, and temperature.

The dominance index value of species at each station was $\leq 0.1$. The species dominance index ranges from 0 to 1 . According to Odum (1993), the species dominance index in the range $\leq 0.50$ is included in the low category. The higher index value of species dominance indicates that the bryophyte community in a particular habitat is dominated by certain species. Conversely, the lower the species dominance index value indicates that no particular species is dominant in the occupied habitat. The low dominance index value also reflects the low level of competition among the species. Each species has the same opportunity to compete for existence in its habitat. From this analysis, the index value of bryophyte species diversity is in the medium category, and the index value of species richness and species dominance is at a low level.

Based on the results that have been described, it can be concluded that Blumah Village is a village that still has a relatively high diversity of plants, especially bryophytes. Based on the identification results, 21 species and 16 families of bryophytes were found. The index value of species diversity was in the medium category. Meanwhile, the index values of species richness and species dominance were at low levels. Subsequent research conducts research and further studies on the benefits of some species need to be addressed so that bryophytes can be utilized as an alternative medicine or other benefits on environmental, agricultural and economic sectors by the community in the future.

\section{ACKNOWLEDGEMENTS}

We thank all parties who participated in taking their time to assist the research process until the completion of the writing of this research article. Henceforth, we would like to thank Mr. Ruspandi, the Bogor Botanical Garden Identification Expert, Sobirin as the documentator, Mrs. Siti Aesiyah., Mr. Saifudin, and the people of Blumah Village who have allowed us to conduct research at that location.

\section{REFERENCES}

Ariyanti, N. S., Bos, M. M., Kartawinata, K., Tjitrosoedirdjo, S. S., Guhardja, E. \& Gradstein, S. R. (2008). Bryophytes on Tree Trunks in Natural Forests, Selectively Logged Forests and Cacao Agroforests in Central Sulawesi, Indonesia. Biological conservation, 141(10), 2516-2527.

Bartram, E. B. (1939). Mosses of the Philippines. Philippine J. Sci., 68, 1-473. 


\section{Jurnal Biodjati 6(1):23-35, May 2021 \\ JURNAL BI@DIATI}

http://journal.uinsgd.ac.id/index.php/biodjati

Bawaihaty, N. I. \& Hilwan, I. (2014). Keanekaragaman dan Peran Ekologi Bryophyta di Hutan Sesaot Lombok, Nusa Tenggara Barat. Jurnal Silfikultur Tropi$k a, 5(1), 13-17$.

Cole, T. C., Hilger, H. H. \& Goffinet, B. (2016). Bryophyte Phylogeny Poster.

Damayanti, L. (2006). Koleksi Bryophyta Taman Lumut Kebun Raya Cibodas. Cibodas: UPT Balai Konservasi Tumbuhan Kebun Raya Cibodas.

Eddy, A. (1988). A Handbook of Malesian Mosses Volume 1. London: Natural History Museum Publications.

Eddy, A. (1990). A Handbook of Malesian Mosses Volume 2. London: Natural History Museum Publications.

Eddy, A. (1996). A Handbook of Malesian Mosses Volume 3. London: HMSO Publications Centre.

Endang, T. (2020). Inventarisasi Jenis-Jenis Lumut (Bryophyta) di Daerah Aliran Sungai Kabura-Burana Kecamatan Batauga Kabupaten Buton Selatan. Jurnal Biologi Tropis, 20(2), 161-172.

Febrianti, G. N. (2015). Identifikasi Tumbuhan Lumut (Bryophyta) Di Lingkungan Universitas Jember Serta Pemanfaatannya Sebagai Buku Nonteks. Skripsi. Universitas Jember.

Gradstein, S. R., \& Regional Center for Tropical Biology (Bogor, Indonesia). (2011). Guide to the Liverworts and Hornworts of Java. Bogor: Seameo-Biotrop.

Goffinet, B. (2008). Bryophyte biology. UK: Cambridge University Press.

Hammer, O., Harper, D. A. \& Ryan, P. D. (2001). PAST: Paleontological Statistics Software Package for Education and Data Analysis. Palaeontologia electronica, 4(1), 1-9.

Hariyanto, S., Irawan, B. \& Soedarti, T. (2008). Teori dan Praktek Ekologi.
Surabaya: Airlangga University Press.

Imu, U. C., Purnamasari, A. B. \& Liana, A. (2019). Identifikasi Tumbuhan Lumut di Kawasan Wisata Taman Nasional Bantimurung Bionature, 20(2), 147151.

Jensen, S., Omarsdottir, S., Bwalya, A. G., Nielsen, M. A., Tasdemir, D. \& Olafsdottir, E. S. (2012). Marchantin A, a Macrocyclic bisbibenzyl Ether, Isolated from the Liverworth Marchantia polymorpha, Inhibits Protozoal Growth in vitro. Phytomedicine, 19(13), 1191-1195.

Lukitasari, M. (2018). Mengenal Tumbuhan Lumut (Bryophyta): Deskripsi, Klasifikasi, Potensi dan Cara Mempelajarinya. Magetan: CV. AE Media Grafika.

Maisyaroh, W. (2010). Struktur Komunitas Tumbuhan Penutup Tanah di Taman Hutan Raya R. Soerjo Cangar, Malang. Jurnal Pembangunan dan Alam Lestari, 1(1), 1-8.

Mulyani, E., Perwati, L. K. \& Murningsih, M. (2015). Lumut Daun Epifit Di Zona Tropik Kawasan Gunung Ungaran, Jawa Tengah. Bioma: Berkala Ilmiah Biologi, 16(2), 76-82.

Odum, E. P. (1993). Dasar-Dasar Ekologi. Terjemahan T. Samingan Edisi Ketiga Pengantar Ekologi. Bandung: CV. Remadja Karya.

Retnowati, A., Rugayah, J. S. R. \& Arifiani, D. (2019). Status Keanekaragaman Hayati Indonesia: Kekayaan Jenis Tumbuhan dan Jamur Indonesia. Jakarta: LIPI Press.

Rini, Z. A. (2019). Identifikasi Lumut di Kawasan Cagar Alam Watangan Puger Kabupaten Jember dan Pemanfaatan Sebagai Booklet. Skripsi. Universitas Jember.

Rugayah, R. A., Windadri, F. I. \& Hidayat, A. 


\section{Jurnal Biodjati 6(1):23-35, May 2021}

\section{JURNAL BIDDJATI}

http://journal.uinsgd.ac.id/index.php/biodjati

(2004). Pedoman Pengumpulan Data

Keanekaragaman Flora. Dalam: Rugayah, Widjaja E A \& Praptiwi (eds.). Bogor: Puslit-LIPI, 5-42.

Ruggiero, M. A., Gordon, D. P., Orrell, T. M., Bailly, N., Bourgoin, T., Brusca, R. C., Cavalier-Smith, T., Guiry, M. D. \& Kirk, P. M. (2015). A Higher Level Classification of All Living Organisms. PloS one, 10(4).

Triantono \& Ichwan, M. (2019). Inventarisasi Tumbuhan Lumut Akuatik di Kawasan Wisata Air Terjun Tancak Panti Kabupaten Jember dan Kegunaannya Sebagai Booklet. Skripsi. Universitas Jember.
Windadri, F. I. \& Rosalina, D. (2017). Rekaman Baru Tumbuhan Lumut Sejati di Pulau Enggano. Buletin Kebun Raya, 20(2), 101-110.

Windadri, F. I. (2014). Lumut Sejati di Kawasan Cagar Alam Gunung Papandayan Garut, Jawa Barat. Berita Biologi, 13(3), 309-320. 